Modern Sociologists

(1) Comte: the Founder of Sociology. By F. S. Marvin. Pp. 216.

(2) Veblen. By J. A. Hobson. Pp. 227.

(London : Chapman and Hall, Ltd., 1936.) 6s. net each.

(1) M.R. MarviN's "Comte", notwithstanding the brevity of treatment imposed by the limitations of the series of which it forms part, is one of the best and most lucid expositions of the doctrines of the founder of 'sociology' extant. Its merits, however, are not confined solely to its treatment of the positive philosophy and the religion of humanity as originally formulated. The author, having in mind the aim of the series to bring the principles of sociological thinkers into relation with the problems of to-day, has essayed the by no means easy task of evaluating the position of Comtian theories at the present time. In so doing, Mr. Marvin has analysed current trends of modern society in thought, in scientific discovery, and in social development, with an acute perception and a sanity of judgment, which not only provide an efficient antidote to current moods of superficial pessimism, but also convey a gospel to scientific workers and practical sociologists.

(2) Veblen is a thinker of a very different order from Comte; and notwithstanding Mr. Hobson's acute and sympathetic analysis of his work, it is difficult to evade the conclusion that his sociological doctrines were little more than a sublimation of personal experience. His early life on a Middle-West farm and in Chicago at the close of the nineteenth century, when the corrupting influence of financial interests was at its height, fundamentally affected his reading of history and his view of the development of society. His interpretation of the evidence of anthropology, upon which much stress is laid by his admirers in the United States, is superficial and lacking in understanding. This view would probably not meet with the assent of the author of this exposition. The brief introductory sketch of the events of Veblen's life given here needs revision as to its dating.

Über Katalyse und Katalysatoren in Chemie und Biologie

Von Alwin Mittasch. Pp. vii +65. (Berlin : Julius Springer, 1936.) 3.60 gold marlss.

A LIFEXIME's work on technical catalysts lies behind this little pamphlet. While Haber proposed and outlined experimentally the idea of nitrogen fixation, and Bosch developed the apparatus for it, Mittasch solved one of the main practical difficulties attached to the process, by the discovery of an iron catalyst of a certain composition.

Few people know more about technical catalysts than does the author; much of the existing knowledge has grown up under his direction and has never been published. It is astonishing how little all this important work has contributed to the elucidation of the principles of catalytic action. The pamphlet gives no scientific views on this subject. Besides reviewing the various aspects of chemical catalysis, it surveys a great number of biological phenomena in which small quantities of substance have big effects : the action of enzymes, poisons, heredity are all spun together in a web of loose analogies. Some of the points referred to are of quite recent date and impress upon the reader the wideness of the author's knowledge. This factual survey may be of some use, even though there is no idea underlying it.

One is reminded of Gudden and Pohl's treatise on photo-electric conductivity which, when introducing the chapter on selenium, notes that this particular field is most obscure owing to the great amount of technical work done in it. It seems that technical research conducted under an employer's authority, in an atmosphere of secrecy, is far less effective in discovering the principles involved in a process than pure research open to world-wide discussion.

M. Polanyi.

\section{Witches and Warlocks}

By Philip W. Sergeant. Pp. $290+15$ plates. (London : Hutchinson and Co. (Publishers), Ltd., 1936.) 12s. 6d.

Dr. Margaret Murray's study of witchcraft in western Europe, which revived the theory of a Dianic cult and brought its manifestations into relation with modern ideas on the character of primitive religion, gave an orientation to the numerous studies of witcheraft which followed, and demanded from her imitators and successors something more than descriptive narrative to justify publication. Mr. Sergeant's claim to serious attention lies in his careful and detailed analysis of the evidence in the cases of the Lancashire witches, and the part played by the Mathers and others in the persecution of the Salem witches in America, as well as in his account of the Elizabethan Dr. Dee and his evil genius Kelly. On the theoretical side he is not equally happy. His knowledge of primitive religion is scarcely adequate to the demand-his reference to totemism seems particularly wide of the mark-nor does his know. ledge of the literature of that subject appear to be extensive.

\section{Aluminium-Legierungen}

Von A. Grützner. Unter Mitarbeit von G. Apel. Teil 1. Patentsammlung geordnet nach Legierungssystemen. Pp. vii +342 . 35 gold marks. Teil 2. Patentsammlung. Nebst einem Markenverzeichnis bekannter Aluminium-legierungen, von Prof. Dr. A. von Zeerleder. Pp. iii $+343-868$. (Zugleich Anhang zu Aluminium Teil A in Gmelins Handbuch der anorganischen Chemie, Achte Auflage, herausgegeben von der Deutschen Chemischen Gesellschaft.) (Berlin: Verlag Chemie, G.m.b.H., 1936.) 54 gold marks. (Ausland preis, 40.50 gold marks.)

THE alloys of aluminium are so numerous that a complete table of them has been compiled, which runs to more than 800 pages and is issued in two parts. The table facilitates reference to the patent literature, and a further useful feature is a supplementary list of all the known alloys of the metal in the alphabetical (or numerical) order of their trade names, together with the names of patent holders and percentage compositions. 